International Journal of Physical Sciences and Engineering
Available online at http://sciencescholar.us/journal/index.php/ijpse
Vol. 2 No. 2, August 2018, pages: $1 \sim 10$
e-ISSN : 2550-6943, p-ISSN : 2550-6951
http://dx.doi.org/10.29332/ijpse.v2n2.127

\title{
Utilizing Turbine Ventilator as Supplier of Electrical Energy Resources For Home Information
}

\author{
$\underset{\text { CrossMark }}{\text { trick for updines }}$ \\ I Wayan Supardi a, Komang Ngurah Suarbawa ${ }^{b}$, I Made Satriya Wibawa c, Made Padmika d, Ni Wayan \\ Dewi Mahayani f I Wayan Wisnawa Saputra $g$ \\ Article history: Received 9 August 2017, Accepted in revised form 1 March 2018, Approved 17 May 2018, \\ Available online 28 May 2018

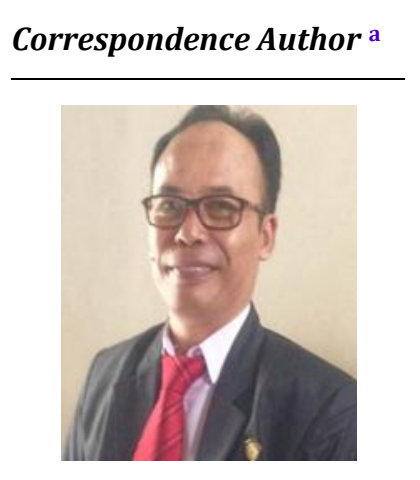

\begin{abstract}
The power plant has been created with turbine ventilator as a source of electrical energy for lighting. Voltage generator generated when wind speed between $0 \mathrm{~m} / \mathrm{s}$ up to $6 \mathrm{~m} / \mathrm{s}$ with no given load is between 0 volts up to 8.38 volts. Generator-generated electricity can be utilized in everyday life after going through several processes like converting the voltage from DC to AC by using a DC to AC inverter and increasing the AC voltage to a 220 -volt voltage using a transformer. In this study using 5 watts LED lamp that can be used to help to light.
\end{abstract}

\section{Keywords \\ Electricity; \\ Generator; \\ Turbine; \\ Ventilator; \\ Wind;}

e-ISSN: 2550-6943, p-ISSN: 2550-6951 ${ }^{\circ}$ Copyright 2018. The Author.

SS Journals Published by Universidad Técnica de Manabí.

This is an open-access article under the CC BY-SA 4.0 license

(https://creativecommons.org/licenses/by-sa/4.0/)

All rights reserved.

\section{Contents}

Abstract

1. Introduction

2. Research Method

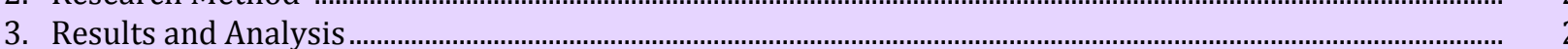

a Department of Physics, Udayana University at Bali, Indonesia, supardi@unud.ac.id

b Department of Physics, Udayana University at Bali, Indonesia

c Department of Physics, Udayana University at Bali, Indonesia

d Department of Physics, Udayana University at Bali, Indonesia

f Department of Physics, Udayana University at Bali, Indonesia

g Department of Physics, Udayana University at Bali, Indonesia 


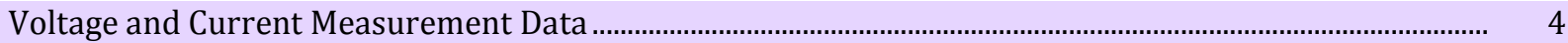

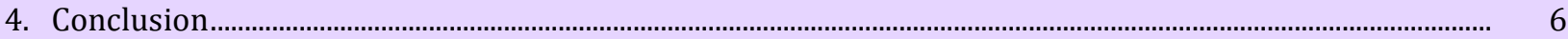

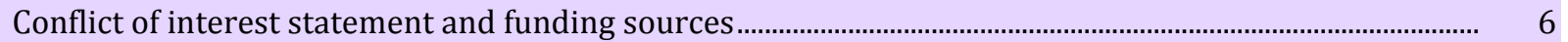

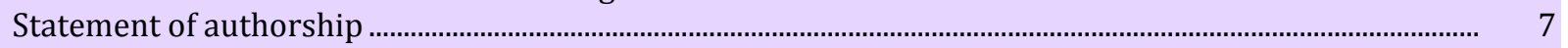

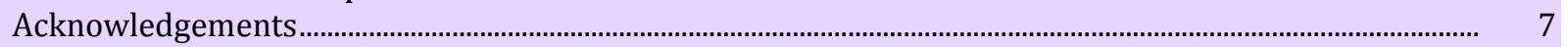

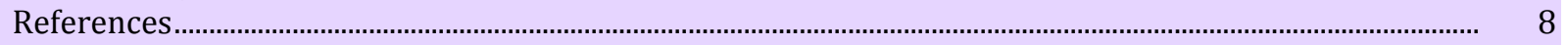

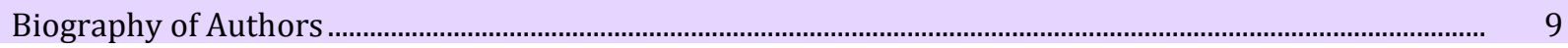

\section{Introduction}

Many methods are used as an electricity source that has been conducted as in the journal entitled power generation roof ventilator [1], electric power generation by using roof top turbine ventilator [2], performance of wind turbine ventilator as electrically generator in boat fishing $[3,7]$, fundamentals of wind energy [4], wind power plant with thermal energy storage for improving the utilization of wind energy $[5,8]$, Wind and Ventilation Turbine (WVT) Generator [6,9], but from the methods that have been done, some are using ordinary propellers which certainly require a stronger wind gust than a turbine. Then some are already using a turbine, but the voltage generated is limited to DC voltage with a voltage of about 5 volts. In addition, there have been used turbines that are equipped with storage on the battery and converter from DC to AC current. But in this method, the storage voltage on the battery is not equipped with automatic storage, so that when the battery is full it will continue to be supplied with an inlet voltage as the turbine spins. This will greatly affect the use of battery life that will certainly have a bad impact on the battery. In this research has succeeded to make power plant by using turbine ventilator and battery as a storage place of voltage, as well as automatic charger circuit on battery and converter DC to AC. In addition, the selection of turbine used in this research is the advantage of turbine ventilator than wind turbine that rotates horizontally is not necessarily require a high place to be able to rotate the turbine hood, and can also be installed on the roof of the house with its function is to reduce the hot air inside or under the turbine the wind is brought out so that the air inside is not too hot. The design of power plants with turbine ventilator as a generator drive is expected to increase the availability of electrical energy for the future. In the present study discussed in part 2 of the series of voltage chargers produced by the turbine ventilator, section 3 discusses the results and discussion and section 4 discusses the conclusions.

\section{Research Methods}

The charger circuit is used to process battery charging or battery safely. Therefore, it will not damage the battery cell or battery when the battery is full. The schematic of the charger circuit is shown in Figure 1.

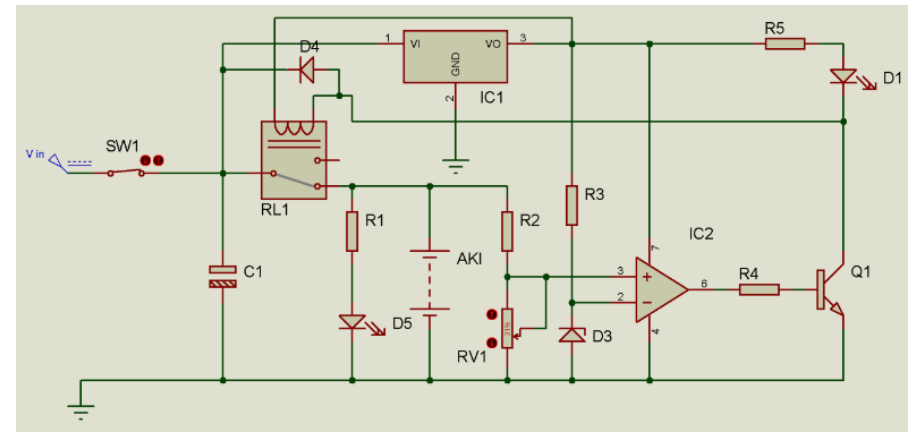

Figure 1. Charger circuit

\section{Results and Analysis}

The result obtained in this research is the design of power plant using ventilator turbine as shown in Figure 2. 


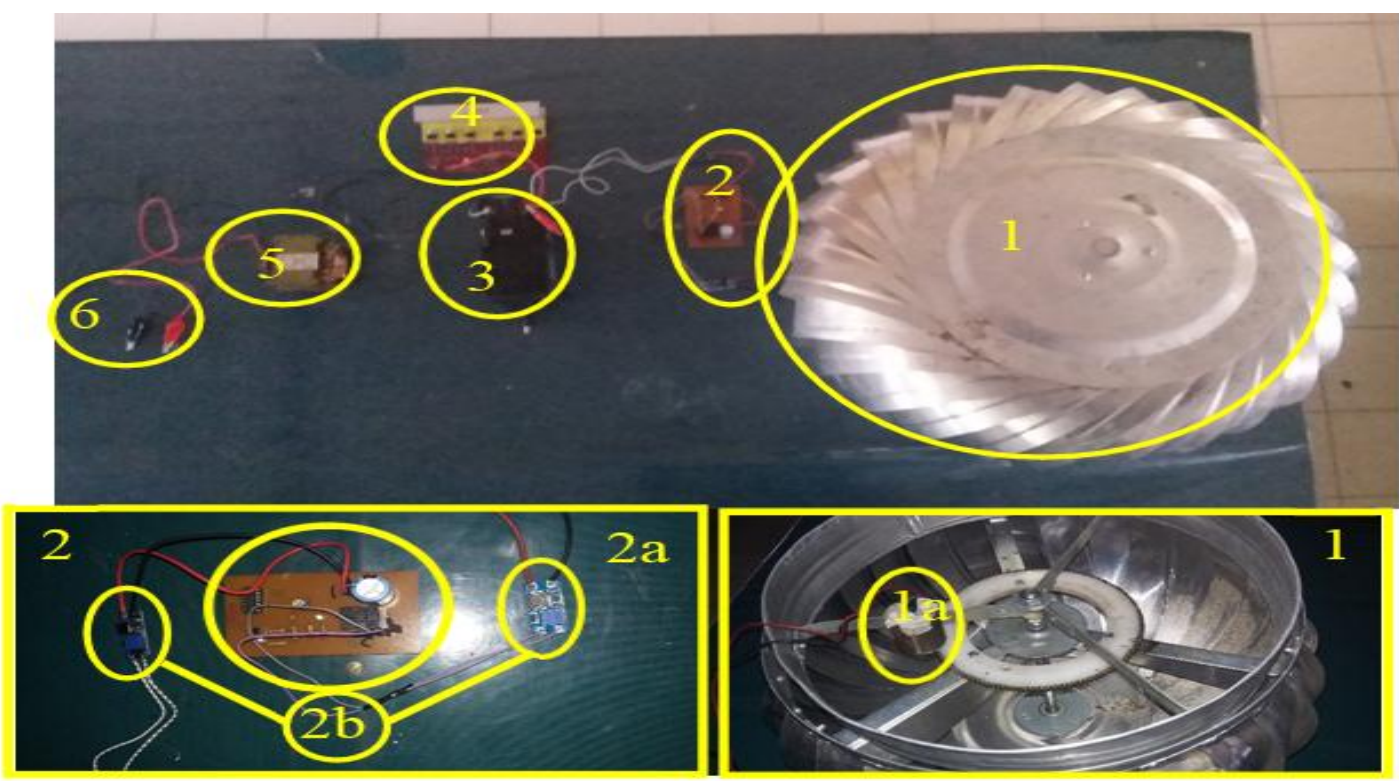

Figure 2. The design of power tools with turbine ventilator as a source of electrical energy for home lighting

The function of each part of the tool as follows:

1. Turbine Ventilator as a generator drive

1a. The generator as a mechanical energy converter to electrical energy

2. Charger circuit

2a. Charging circuit for input from battery or battery charging

2b. Step up the DC to DC inverter to raise the voltage from the generator

3. The 12-volt battery as battery or power saver

4. Inverter $\mathrm{DC}$ to $\mathrm{AC}$ to change from direct voltage (DC) to voltage back and forth (AC)

5. Transformation or transformer to raise power to 220 volts

6. The output of this circuit which will later become the input for electronic equipment

The ventilator turbine is able to rotate due to wind velocity factor and the air pressure difference factor inside or below the turbine with the air outside the turbine. The wind gust from the fins of the ventilator turbine can drive the fins and result in the turning off the ventilator turbine. Inside the turbine, ventilator mounted gears that connect the turbine ventilator with a DC generator. The fin form of the turbine hood is designed with one-way rotation. Combining the number of gears in the ventilator turbine with the one at the end of the generator is required to get the number of turns that multiply more between the spin of the generator and the turbine spin of the ventilator. The gear ratio used in the turbine with the gears on the generator is 125 to 10 . A lap turbine ventilator will rotate the generator 12.5 times.

The generator converts mechanical energy to DC electrical energy. The generator generated voltage is not stable. To stabilize the output of the generator used the MT3608 module with a minimum input of 2 volts. The stabilized voltage will then become the input for the charging circuit. The battery used in this study is a battery with a voltage of 12 Volt. For charging a 12-volt battery requires an input voltage of 13.8 volts. To make a 12 -volt output voltage charger to be a 13.8-volt voltage required MT3608 module.

This charging circuit acts as a charger from the battery. If the battery is full then charging will be stopped, and when the battery is not in full condition, it will be refilled. Charging battery will be done if the voltage used is $115 \%$ compared with the maximum voltage of the battery.

Supardi, I., Suarbawa, K., Wibawa, I., Padmika, M., Mahayani, N., \& Saputra, I. (2018). Utilizing turbine ventilator as supplier of electrical energy resources for home information. International Journal Of Physical Sciences And Engineering (IJPSE), 2(2), 1-10. doi:10.29332/ijpse.v2n2.127 


\section{Voltage and Current Measurement Data}

Results Measurements of voltages and currents generated by generators as in Table 1 to Table 2 with search data each performed five times.

Table 1

Wind speed data with respect to the voltage

\begin{tabular}{cccccccc}
\hline \multirow{2}{*}{ No } & \multicolumn{6}{c}{ Wind Velocity } & \multicolumn{5}{c}{ Led Voltage $(V L)$ volt } & \multirow{2}{*}{ Average (V) } \\
\cline { 2 - 6 } & $(\mathrm{m} / \mathrm{s}) \pm 0.1$ & $\mathrm{~V}_{\mathrm{L} 1}$ & $\mathrm{~V}_{\mathrm{L} 2}$ & $\mathrm{~V}_{\mathrm{L} 3}$ & $\mathrm{~V}_{\mathrm{L} 4}$ & $\mathrm{~V}_{\mathrm{L} 5}$ & \\
\cline { 1 - 6 } 1 & 0 & 0,00 & 0,00 & 0,00 & 0,00 & 0,00 & 0,00 \\
2 & 1 & 0,00 & 0,00 & 0,00 & 0,00 & 0,00 & 0,00 \\
3 & 2 & 1,32 & 1,35 & 1,30 & 1,30 & 1,29 & 1,31 \\
4 & 3 & 1,71 & 1,72 & 1,71 & 1,72 & 1,72 & 1,72 \\
5 & 4 & 1,73 & 1,72 & 1,71 & 1,71 & 1,72 & 1,72 \\
6 & 5 & 1,75 & 1,75 & 1,75 & 1,75 & 1,76 & 1,75 \\
7 & 6 & 1,76 & 1,75 & 1,76 & 1,75 & 1,76 & 1,76 \\
\hline
\end{tabular}

From Table 1, the graph of wind velocity data with the voltage shown in Figure 3.

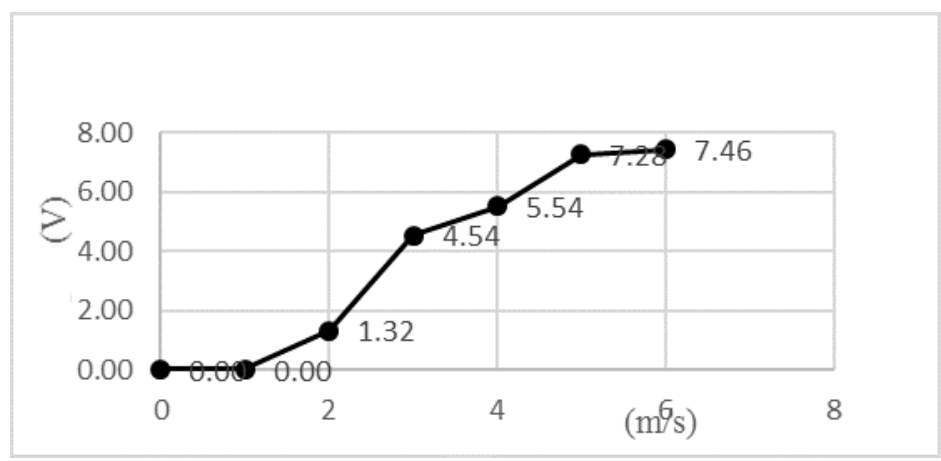

Figure 3. Graph of voltage load to wind speed

In Figure 3, seen between $0 \mathrm{~m} / \mathrm{s}$ up to $1 \mathrm{~m} / \mathrm{s}$ no voltage exists. This happens because the turbine hood does not rotate at that speed. The generator starts to output when the wind speed is more than $1 \mathrm{~m} / \mathrm{s}$ and increases steadily to a speed of $6 \mathrm{~m} / \mathrm{s}$. However, when the wind speed between $5 \mathrm{~m} / \mathrm{s}$ and $6 \mathrm{~m} / \mathrm{s}$ increase the voltage generated by the generator decreases compared to the initial moment of the increase in voltage.

Table 2

Data on wind velocity to currents

\begin{tabular}{cccccccc}
\hline \multirow{2}{*}{ No } & Wind Velocity & \multicolumn{7}{c}{ Flow with total load (I) $\mathrm{mA}$} & \multirow{2}{*}{ Average (mA) } \\
\cline { 3 - 7 } & $(\mathrm{m} / \mathrm{s}) \pm 0.1$ & $\mathrm{I}_{1}$ & $\mathrm{I}_{2}$ & $\mathrm{I}_{3}$ & $\mathrm{I}_{4}$ & $\mathrm{I}_{5}$ & \\
& 0 & 0,00 & 0,00 & 0,00 & 0,00 & 0,00 & 0,00 \\
2 & 1 & 0,00 & 0,00 & 0,00 & 0,00 & 0,00 & 0,00 \\
3 & 2 & 0,24 & 0,11 & 0,20 & 0,35 & 0,19 & 0,22 \\
4 & 3 & 47,50 & 48,30 & 45,80 & 47,70 & 46,20 & 47,10 \\
5 & 4 & 64,70 & 63,80 & 62,60 & 63,40 & 62,70 & 63,44 \\
6 & 5 & 86,20 & 84,10 & 85,80 & 87,10 & 87,40 & 86,12 \\
7 & 6 & 134,60 & 127,10 & 126,70 & 120,10 & 124,00 & 126,50 \\
\hline
\end{tabular}

From Table 2, the graph of wind velocity data with the current shown in Figure 4. 


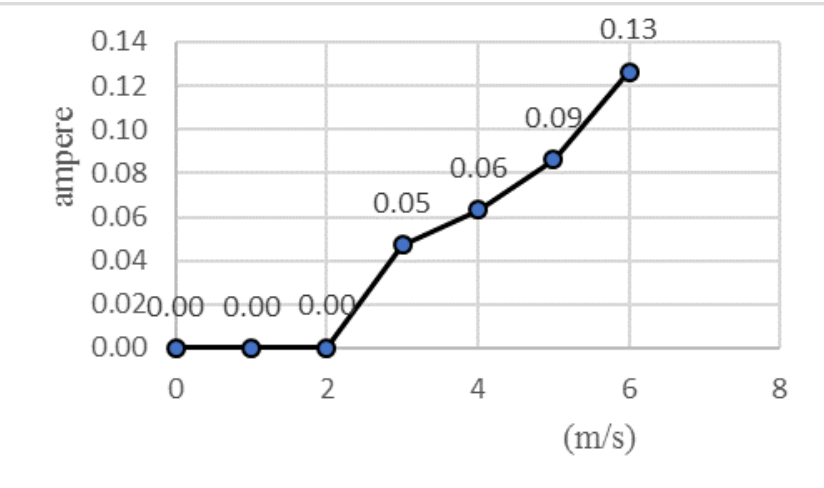

Figure 4. Graph of the relationship between wind speed and current

From Figure 4, the generator begins to generate a current or start current in the Avometer when the wind speed that blows the turbine hood is greater than $2 \mathrm{~m} / \mathrm{s}$. The maximum average current generated by the generator i.e., at wind speed $6 \mathrm{~m} / \mathrm{s}$ is $0.13 \mathrm{~A}$.

Battery charging data using two categories of wind speed i.e., wind with a speed of $4 \mathrm{~m} / \mathrm{s}$ and $5 \mathrm{~m} / \mathrm{s}$. The time interval when searching data is 30 minutes. The results obtained from the charging battery are shown in Table 3 to Table 4.

Table 3

Battery charge data with wind speed $4 \mathrm{~m} / \mathrm{s}$

\begin{tabular}{cccc}
\hline No & $\begin{array}{c}\text { Wind Velocity } \\
(\mathrm{m} / \mathrm{s})\end{array}$ & $\begin{array}{c}\text { Time } \\
\text { (minute) }\end{array}$ & $\begin{array}{c}\text { Voltage } \\
\text { (volt) }\end{array}$ \\
\hline 1 & 4,00 & 0 & 6,86 \\
2 & 4,00 & 30 & 7,67 \\
3 & 4,00 & 60 & 8,07 \\
4 & 4,00 & 90 & 8,32 \\
5 & 4,00 & 120 & 8,56 \\
\hline
\end{tabular}

From Table 3, the graph can be made as shown in Figure 5.

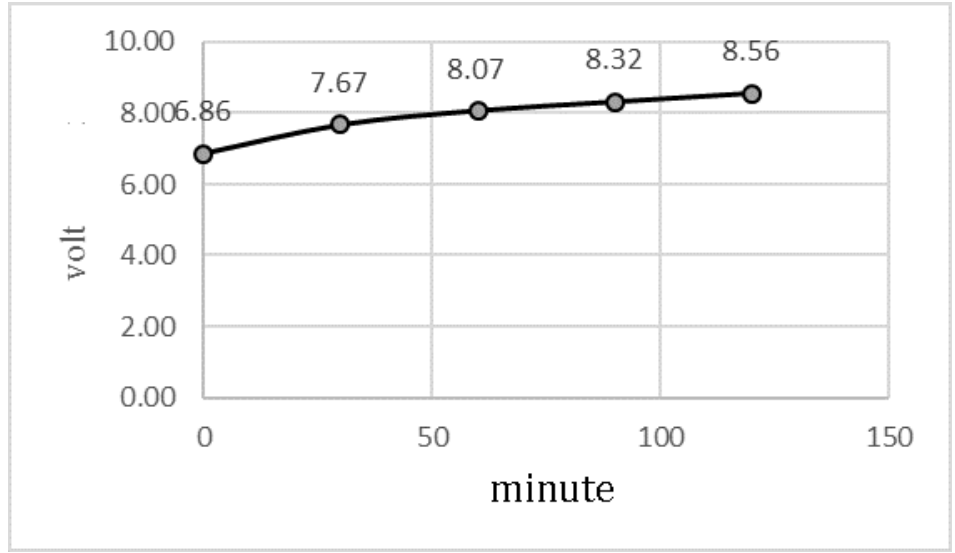

Figure 5. Charging graph with wind speed $4 \mathrm{~m} / \mathrm{s}$

Supardi, I., Suarbawa, K., Wibawa, I., Padmika, M., Mahayani, N., \& Saputra, I. (2018). Utilizing turbine ventilator as supplier of electrical energy resources for home information. International Journal Of Physical Sciences And 
Charging graph with wind speed $4 \mathrm{~m} / \mathrm{s}$ shown in Figure 5 . The initial voltage of the battery is 6.86 volts, then the first 30 minutes rise to 7.67 volts, and continues to increase until completion of the data search for 120 minutes every 30 minutes once the voltage on the battery is recorded. The total increase of the voltage on the battery when 0 minutes to 120 minutes is 1.70 volts.

Table 4

Battery charge data with wind speed $5 \mathrm{~m} / \mathrm{s}$

\begin{tabular}{cccc}
\hline No & $\begin{array}{c}\text { Wind Velocity } \\
(\mathrm{m} / \mathrm{s})\end{array}$ & $\begin{array}{c}\text { Time } \\
\text { (menit) }\end{array}$ & $\begin{array}{c}\text { Voltage } \\
\text { (volt) }\end{array}$ \\
\hline 1 & 5,00 & 0 & 6,92 \\
2 & 5,00 & 30 & 8,00 \\
3 & 5,00 & 60 & 8,52 \\
4 & 5,00 & 90 & 8,88 \\
5 & 5,00 & 120 & 9,13 \\
\hline
\end{tabular}

From Table 4, the graph can be made as shown in Figure 6.

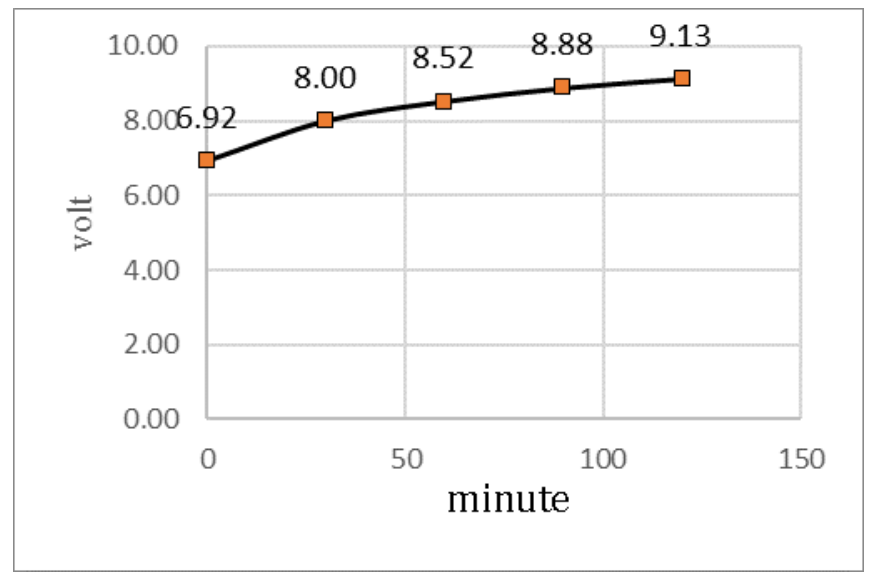

Figure 6. Grain charging battery with wind speed $5 \mathrm{~m} / \mathrm{s}$

Charging graph with a wind speed of $5 \mathrm{~m} / \mathrm{s}$ is shown in Figure 6. The initial voltage of the battery is 6.92 volts. Charging at this speed is the same as the first charging that is 120 minutes long which every 30 minutes of voltage on the battery is recorded. Battery voltage increased by 2.21 volts over 120 minutes.

The current and voltage of electric that has been stored in the battery is a DC power, while the output commonly used in homes is the AC voltage, so it takes a DC to AC inverter tool whose function is to convert $\mathrm{DC}$ voltage into $\mathrm{AC}$ voltage. In addition to $\mathrm{DC}$ to $\mathrm{AC}$, inverters are also needed Step-up transformers to increase the output voltage from the DC to AC inverter in accordance with the charging battery or in this case using a 12 -volt battery to 220 volts.

\section{Conclusion}

Generator-generated electricity can be utilized in everyday life after going through several processes like converting the voltage from DC to AC by using a DC to AC inverter and increasing the AC voltage to a 220 -volt voltage using a transformer. In this study using 5 watts LED lamp that can be used to help to light.

\section{Conflict of interest statement and funding sources}

The author(s) declared that (s)he/they have no competing interest. The study was financed by Udayana University through the Grant of Study Program (PNBP) for the budget the year 2017 


\section{Statement of authorship}

I/We certify that I/We have sufficiently participated in the conception and design of this work and data analysis (wherever applicable), as well as the manuscript writing, to take public responsibility for it. I/We believe this manuscript represents a valid work. I/We have reviewed the final version of the manuscript and agreed to publish. Neither the manuscripts nor those that have nearly the same content under my authorization have been published or are being considered for publication elsewhere, the article does not have a conflict with existing copyright or other third party rights. Next, I/We prove that I/We will generate the data on which the script is based on an inspection by the editor or assignee if requested. This article does not contain any material that may be unlawful, defamatory, or otherwise published.

\section{Acknowledgments}

The authors praise gratitude prayed to the Almighty God due to the blessing the article is completed as well. We also thank the Rector of Udayana University as the fund holder, Institute of Research and Community Service (LPPM), Udayana University that has provided an opportunity to carry out research, the Dean of Udayana University, Faculty of Mathematics and Natural Sciences, Department of Physics, Faculty of Mathematics and Natural Sciences, and our friends in physics program, Udayana University.

Supardi, I., Suarbawa, K., Wibawa, I., Padmika, M., Mahayani, N., \& Saputra, I. (2018). Utilizing turbine ventilator as supplier of electrical energy resources for home information. International Journal Of Physical Sciences And 


\section{References}

1. Tong, W. (2010). Wind power generation and wind turbine design. WIT press. View in (Google Scholar)

2. S. Z. Akshay, P. S. Rahul, J. N. Sonali and S. P. Pravin. (2016). Electric Power Generation by Using Roof Top Turbine Vantilator, International Journal of Current Trends in Engineering and Research (IJCTER), (2), 474 480.

View in (Article)

3. Daut, I., Shatri, C., Irwanto, M., Syafawati, A. N., \& Shema, S. S. (2011, February). Power Generation Roof Ventilator. In 2011 International Conference on Environment and Industrial Innovation IPCBEE (Vol. 12). View in (Google Scholar)

4. Liu, C., Cheng, M. S., Zhao, B. C., \& Dai, Z. M. (2017). A Wind Power Plant with Thermal Energy Storage for Improving the Utilization of Wind Energy. Energies, 10(12), 2126.

View in (Google Scholar)

5. L. R. Corvis and P. Kristiana. (2015). Performance of Wind Turbine Ventilator as Electricity Generator in Boat Fishing, International Journal of Research in Engineering and Technology (IJRET), 04, 108 - 112. View in (Artcile)

6. L. Anthony and M. Jacob, Wind and Ventilation (WVT) Generator, Electrical Engineering Department, (2014), 1 - 36.

View in (Google Scholar)

7. Cedeño, M. L. D., Arteaga, M. G. D., Pérez, A. V., \& Arteaga, M. L. D. (2017). Regulatory Framework for Renewable Energy Sources in Ecuador Case Study Province of Manabí. International Journal of Social Sciences and Humanities (IJSSH), 1(2), 29-42.

View in (Google Scholar) (CrossRef)

8. Jurado, W. C. C., Pérez, A. V. P., Quiroz, A. M. V., \& Gámez, M. R. (2017). Environmental Impact On Electrical Networks Near The Manabita Litoral. International Journal of Life Sciences (IJLS), 1(2), 18-27. View in (Google Scholar) (CrossRef)

9. Gámez, M. R., Pérez, A. V., Será, A. S., \& Ronquillo, Z. M. (2017). Renewable Energy Sources and Local Development. International Journal of Social Sciences and Humanities (IJSSH), 1(2), 10-19.

View in (Google Scholar) (CrossRef) 


\section{Biography of Authors}

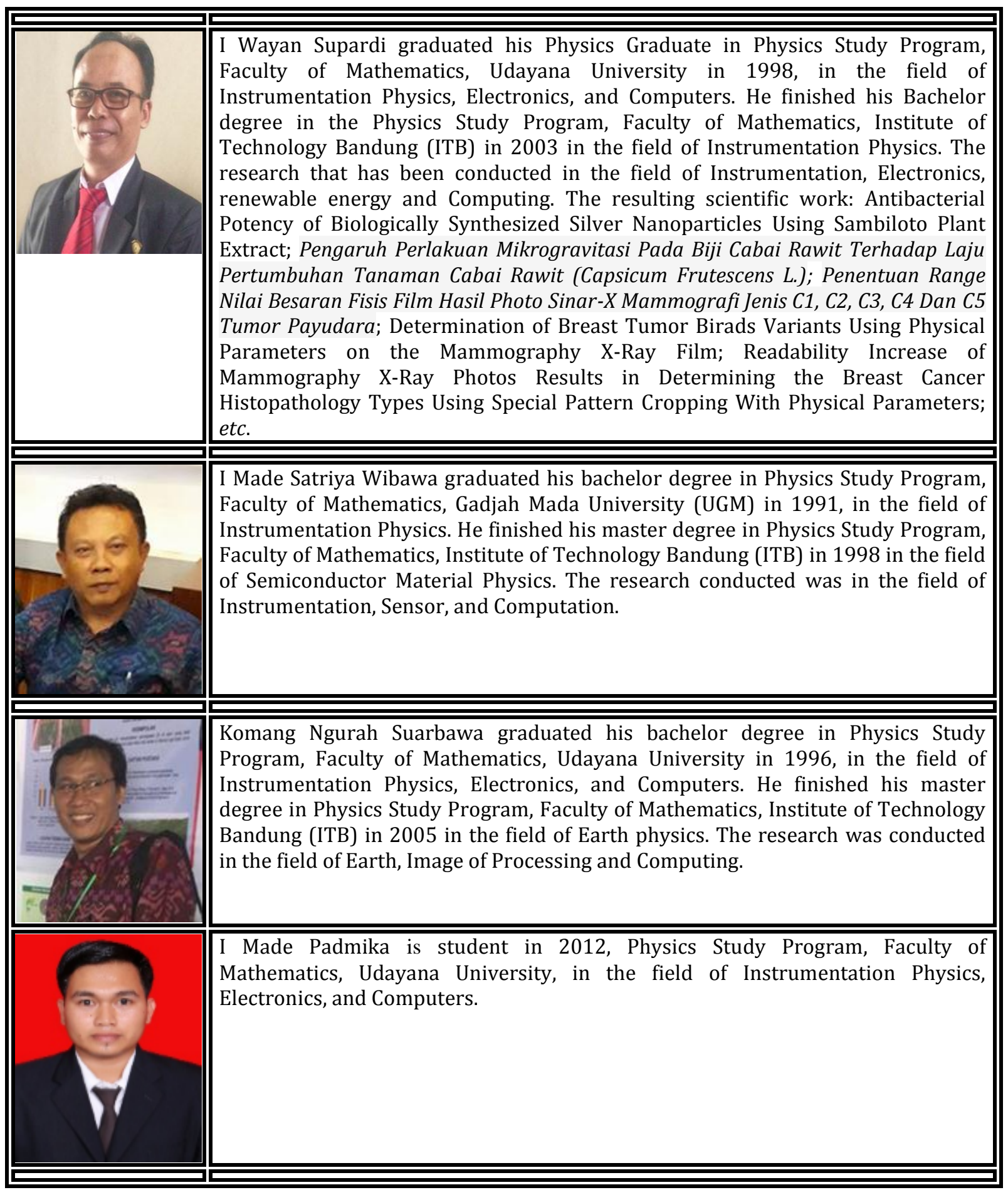

Supardi, I., Suarbawa, K., Wibawa, I., Padmika, M., Mahayani, N., \& Saputra, I. (2018). Utilizing turbine ventilator as supplier of electrical energy resources for home information. International Journal Of Physical Sciences And Engineering (IJPSE), 2(2), 1-10. doi:10.29332/ijpse.v2n2.127 


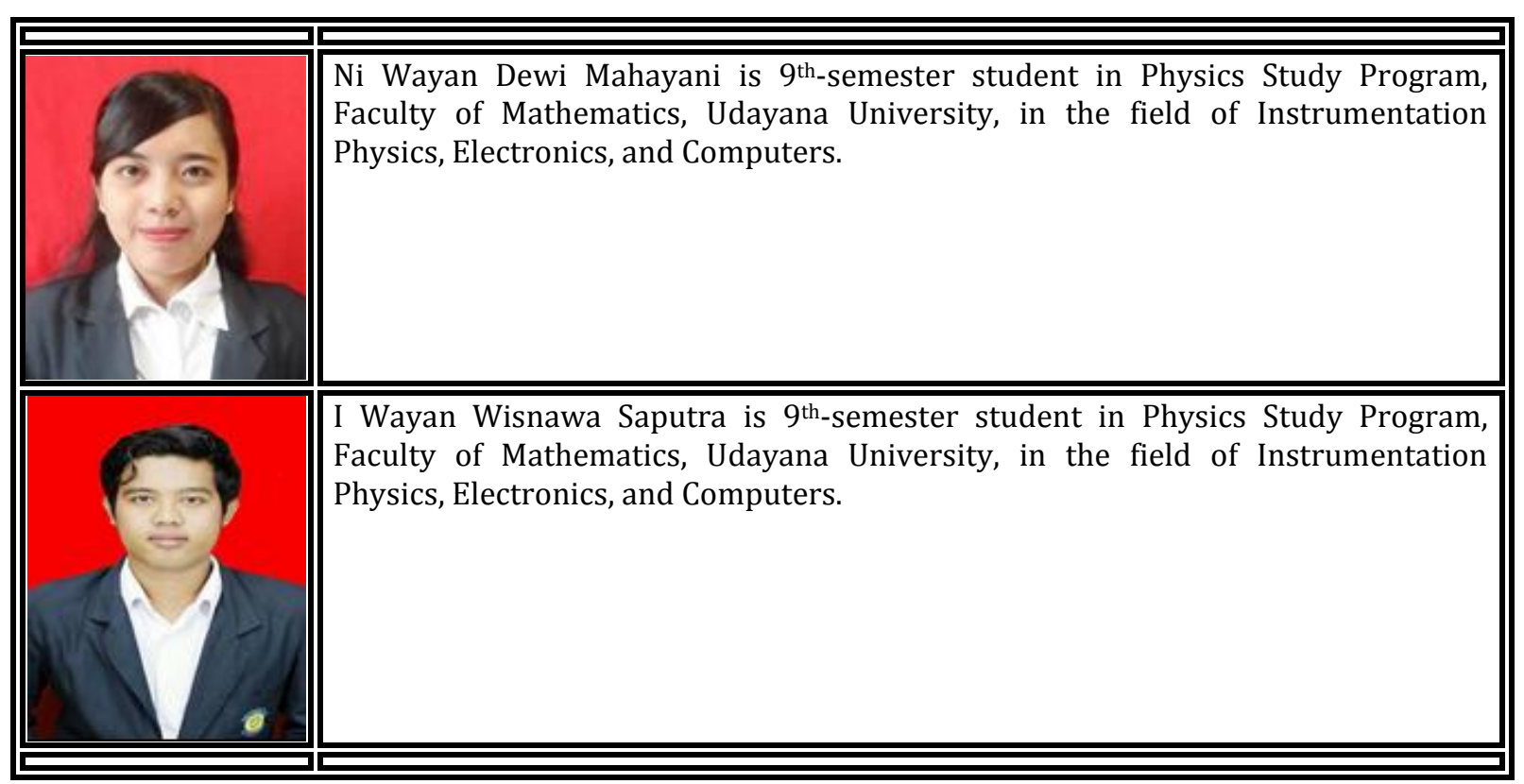

